\title{
THE NEGOTIATION, RATIFICATION, AND IMPLEMENTATION OF TREATIES IN CANADA AND AUSTRALIA
}

\author{
Ronalo I. Cheffins, Assistane Professor of Law, McGill University \\ Member of the British Columbia Bar
}

Canada and Australia, because of their history and position in the British Commonwealth, do not lend themselves to many generalizations about the generic problems of federalism and treaty making. Their treaty problems can be approached from several angles. This paper will concentrate basically on the problem of implementation of international treaties at the domestic level ${ }^{2}$, although any discussion of implementation must, of necessity, treat in detail the question of where the powers of negotiation and ratification reside. The problems of treaty implementation, moreover, must be recognised as deriv. ing their importance only as an aspect of the wider problem of the federal power struggle in Australia and Canada. In both countries, and particularly in the latter, a continual contest wages between the central and regional governments over the division of legislative power. There are ever increasing indications that several basic forces have tended, and are tending, to diminish the power of the regional governments. War and depression, the increasing demand for social services, and an increasing participation in international affairs all have their impact on this trend. All tend to demand an ever increasing amount of control by the central government in every federal state, not excluding Canada and Australia.

Unfortunately for the advocates of regional rights, the pressures exerted by these forces show signs of increasing, rather than decreasing, with the consequent result that the strains upon federalism will tend to increase. On the other hand, one must not suppose that these problems will be quickly and easily resolved, since, in both countries federalism is a deeply rooted thing. As Professor Wheare has observed,

Nor should it be imagined that the rensons which originally led the regions to make a federal and not a unitary union have by now entirely ceased to operate. Quebec is the most atriking example of this fact. The desire of that province to safeguard her distinct language, race and religion and her historical identity as a distinct government, led her to insist that the federal principle be embodied in the Canadian constitution. Those forces still prevail. Indeed they are stronger than ever. Whatever modifications may be introduced into the Canadian federal government it can be prophesied that the federal principle could not be removed entirely from the government, except at the price of Quebec's secession from the union. The same may be said of Western Axstralia, though perhaps not to the same degree."

It is only when one takes into account these reasons for the creation and the continued maintenance of the federal system in both Canada and Australia that the practical importance of determining how treaties should be implemented is fully realised. As already mentioned, the ever increasing role of the two countries in international affairs has tended to increase the importance of

${ }^{1}$ For material concerned with the effect of constitutional limitations on public international law see: J. F. Northey, "Constitutional Limitations as Affecting the Validity of Treaties",

University of Toronto Law Journal, v. 11, 1956, p. 175-201.

2K. C. Wheare, Federal Government, 3d ed., 1953, p. 256. 
central governments. Co-incident with increased participation in international affairs has been the necessity for them to enter into international treaties and agreements. The question of how and by whom these treaties should be implemented goes to the core of the struggle between the central and regional governments over the division of legislative authority.

The people of Quebec, by way of example, have watched Canada's involvement in world affairs with considerable misgiving, preferring to follow a role of isolation. Accordingly, the thought that the federal government, with its English-speaking majority, could encroach upon provincial autonomy under the pretension of implementing an international treaty is indeed a frightening prospect to this French-speaking, Catholic province, and, to a somewhat lesser degree, to the remaining provinces.

It is not, however, my purpose to deal at any length with this issue, but merely to illustrate that the treaty issue in both Canada and Australia is not a purely academic one. On the contrary, it is an issue of vital contemporary political importance. "States Rights" advocates in both nations recognise that unlimited power, vested in a federal government, to implement treaties, could serve to reduce the regional governments to mere administrative agencies, as has been the case in India. It is interesting to note that here, where the provincial governments are generally recognised to be mainly administrative in character, the treaty problem is specifically resolved in favour of the central government. The Indian Constitution provides that "Parliament has power to make any law for the whole or any part of the territory of India for implementing any treaty, agreement or convention with any other country or countries, or any decision made at any international conference, association, or other body." 3 Strong advocates of provincial and states rights in Canada and Australia recognise that a judicial interpretation of their respective constitutions, along the lines spelled out in India's with respect to the federal government's power to implement treaties, would present their central governments with a very potent constitutional weapon, indeed. Provincial politicians tealize that a complete control over treaty implementation, in the hands of the central government, would serve only to divert to it some of their jealously guarded power.

By way of comparison, in the United States the treaty conflict takes a slightly different form, due to the constitutional structure of the country. There the struggle tends to be between the executive and certain legislators who are anxious to curb the executive's tremendous power with respect to negotiation and implementation of treaties. The political forces seeking to limit the President's power in this respect have generally been identified with Senator John Bricker of Ohio.' The battle reached such intensity that the so-called Bricker amendment was proposed, though subsequently defeated. Bricker and his supporters, however, remained undaunted and have now prepared a second,

TThe Constitution of India, 1950, Article 253.

4 For a statement of the Bricker point of view see: Felix Magley, Treaty Law and the Constitution; a Study of the Bricker Amendment, 1953. 
slightly altered version ${ }^{5}$, which has not yet been formally proposed as an amendment.

The political struggle in Canada and Australia over the treaty power has not taken, and is unlikely to take on, the ferocity of that in the United States. Nevertheless, the political significance of the treaty issue must not be lost sight of, because it has been and will be a significant obstacle to any attempts to resolve this problem. As both countries increase their respective roles in the international sphere, the issue cannot help but take on greater significance, because along with some of the factors mentioned earlier, such as social security demands, they have produced a crisis in all genuine federal systems. The treaty problem, particularly in respect to the question of implementation, is only one vital aspect of this total struggle between the political forces within the federal state.

The present treaty problems of Canada and Australia cannot be understood except in the light of their historical development. Unlike most new countries Australia and Canada did not, overnight, find themselves autonomous nations, vested with the international responsibilities usually associated with a sovereign state. International autonomy came slowly for both; it was an evolving process, taking place over a substantial period of time. An understanding of this slow evolutionary trend toward complete independence is of vital importance in attempting to understand the treaty problem of those two nations.

Australia's and Canada's positions as former British Colonies makes their march towards full power to negotiate and implement treaties for themselves, very similar. As a general rule, if one dominion obtained greater freedom to conduct international relations, this benefit was bestowed simultaneously, or shortly thereafter, on the other dominions. Thus a great deal of time can be saved by treating the international evolution of the British Dominions as a whole. It will be noticed, however, that this historical introduction will focus mainly on Canadian-British relationships. This is owing to the fact that Canada, for various reasons, notably her geographic position, ethnic composition, and larger population, tended to lead the way towards Dominion autonomy. Thus, in most respects, the struggle of the dominions was interdependent; the gain of one was the gain of all, and considerable time can be saved by treating the historical aspects of the treaty-making power in Canada and Australia at one time.

The Canadian Constitution, more commonly known as the British North America Act, was passed in 1867, and the Australian Constitution, or Commonwealth of Australia Constitution Act, in 1900. Both were acts of the Parliament of the United Kingdom. At the times of their passage the foreign relations of Canada and Australia were controlled and conducted by Great Britain. As a result, no really adequate provision was made, in either constitution, for a treaty-making power. Section 132 of the British North America Act provides that "the Parliament and government of Canada shall have all powers necessary or proper for performing the obligations of Canada or of any

'New York Times, January 8, 1957. 
provinces thereof, as part of the British Empire, towards foreign countries, arising under treaties between the Empire and such foreign countries."

Evidence seems to support the conclusion that, at the time the Act was passed, Section 132 was merely a treaty implementation power. Professor Zelman Cowen states with respect to the section, "What was contemplated was that the Canadian Parliament or government might take appropriate steps to implement locally treaty arrangements into which the mother country might enter." Professor Hendry reaches the same conclusion on this subject, arguing that,

At the time of confederation, Section 132 had nothing to do with Canada's sapacity to enter into international agreements. There was only one state, namely the British Empire, and only one Crown for treaty making. But this did not mean that the Imperial authorities could enter into international agreements which would be applicable ipso facto as the law of the land in Canada. The constitutional practice was already well established at this time that legislation was required for the implementation of treaties that altered existing law or imposed a change on British subjects. The conclusion then, is inevitable: the Section was intended to give the central authority the legislative power to fulfill the obligations which had been made by the Imperial authorities.;

In the Australian Constitution all reference to treaty making was left out of the final draft. The Parliament of the Commonwealth was given the power, by Section 51 (xxix) to make laws for "the peace, order and good government with respect to external affairs." Cowen makes the point that the "original form of the legislative power under Section 51 (xxix) has been with respect to

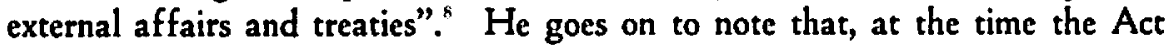
was passed, it was generally agreed that the treaty making power in regard to Australia was in the hands of the government of the United Kingdom. He states the "reference to treaties was deleted lest it be thought that there was any Australian treaty making power"." For the same reason the reference to treaties was also dropped out of another section of the original constitutional draft. Clause 7 of the Bill of 1891, which put forward the new constitution, stated that "The Constitution established by the Act, and all laws made by the parliament of the Commonwealth in pursuance of the powers conferred by the Constitution, and all treaties made by the Commonwealth, shall according to tenor, be binding on the courts, judges, and people of every state, and of every part of the Commonwealth, anything in the laws of any state to the contrary notwithstanding"." Hendry notes that the phrase "and all treaties made by the Commonwealth" was omitted from the final draft of the Constitution, in the same way as the phrase "and treaties", mentioned previously, was deleted from placitum xxix. ${ }^{11}$

The movement towards full treaty making responsibility in the self-governing Dominions can best be studied by means of a several part chronological division. First, of course, is the pre-1914 period. An examination of the problem in Australia and Canada during this time demands recognition of two

'Z. Cowen, Treaty Making and Treaty Enforcement Powers, 1954, p. 29.

7J. L. Hendry, Treaties and Federal Constitutions, 1955, p. 28,

sowen, op. cil., p. 30.

olbid., p. 31.

10Quoted in Hendry, op. cit., p. 33.

$1176 i d .$, p. 33. 
types of treaties: those dealing on the one hand with commercial problems, ${ }^{12}$ and on the other, treaties dealing with non-commercial and political matters. It is essential that this distinction be made, because of the fact that the Dominions achieved effective control over negotiation of commercial treaties before similar autonomy with respect to political treaties.

Originally treaties were concluded on behalf of the colonies by agents of the British government. With respect to commercial treaties, however, considerable headway was made in securing recognition of the rights of both Canada and Australia. Gradually colonial representatives came to serve as advisors in treaty negotiation and conclusion. Finally, they were appointed to serve as plenipotentiaries, along with the British representatives. Further significant gains were made in 1877 when "it was conceded that British commercial treaties should no longer be made applicable to the colonies without thcir assent, and from 1882 every treaty contained, if possible, a clause permitting separate adherence for the colonies. In 1899 this was carried farther, and the right of separate withdrawal was secured."13

Another significant advance was made in 1907, when a Canadian-French treaty was negotiated exclusively by Canadians, the signature of the British official being only a formality. "Thus by 1914 Canada had advanced to an effective position in the matter of securing local trade treaties. There was still involved, however, the intervention of the Imperial government in the grant of the authority to negotiate, and the necessity of the joint signature of the British Ambassador, and the ratification of the treaty, when concluded, by the Crown on the advice of the Imperial Ministry." ${ }^{14}$ These were largely formalities but Canada several times circumvented them by signing local or informal agreements with other countries. They were not regarded as treaties and it was thus unnecessary to resort to the formal methods required in negotiating normal treaties. An informal agreement, signed in 1911 with the U.S.A., to provide for trade reciprocity, however, led to the downfall of the then current Canadian government, accordingly discrediting, for some time thereafter, the informal agreement. Macdonald sums up by stating that "the position of Canada in respect of its external trade relations before the War was that Canada freely negotiated her own commercial treaties without control or interference except of a formal character; while no British trade treaties bound her except by her expressed consent". ${ }^{1 s}$

With respect to political treaties the path to autonomy proved considerably more difficult. The formalities of making political treaties closely approximated those of making commercial treaties. The general custom was to allow Dominion delegates to take part in the negotiation of political treaties directly affecting a Dominion's interest, but, unlike the practice governing commercial treaties, the British delegate played the leading role. With respect to political

12For a detailed discussion of the position of the Dominion with respect to commercial treaties sec: A. G. Dewcy. The Dominion and Diplomacy, 1929, v. 1, p. 151-215.

19A. B. Keith, Dominion Autonomy in Practice, 1929, p. 52.

14V. C. Maedonald, "Canada's Power to Perform Treaty Obligations", 11, Can. Bar Rev., p. 584.

151bid., p. 586. 
treaties involving the whole Empire, and having only an indirect effect on the Dominions, negotiations were concluded exclusively by the Imperial Government. Dawson notes, however, that "the Imperial Conference of 1911 was able to secure a limited and cautious commitment from the Asquith government which promised possible consultation in the future when the interests of the Dominions were involved". ${ }^{16}$ But the dependent position of the Dominions, with respect to political treaties remained basically undisturbed. Macdonald quite plainly summarizes the position of Canada, and indirectly, of all the Dominions with respect to political treaties before World War I.

Such treaties whether concerned with Empire interests generally or Canadian interests specially were made in the name of the King, on the advice of his ministers in Great Britain, as to the grant of power to the negotiators and the ratification of the treaty when concluded, and there was no doubt that whether or not the governments of British North America before 1867, or of Canada after 1867, consented to them they were automatically bound thereby. 17

This, however, should not obscure the fact that real gains had been made. In practice, if not in theory, the Dominion had acquired control over their own commercial treaties, and with respect to political treaties in which they had a direct interest they were beginning to exert an increasing influence.

The leisurely pace by which the Dominions were progressing towards greater autonomy was suddenly distupted, in 1914, by their participation in the First World War. Gains in the direction of autonomy, which, under ordinary cireumstances, would have only been achieved very slowly, suddenly became reality. Included in these advances was an increased Dominion power with respect to the conclusion of treaties. After the end of the War, and just prior to the signing of the Peace Treaty, Sir Robert Borden, the then Prime Minister of Canada, secured the approval of other Dominion leaders to the suggestion that each of the Dominions should sign the peace treaties separately. ${ }^{18}$ In view of their significant contributions to the war effort it would have been difficult, if not impossible, for the British government to turn down this request. At the same time, however, the various Dominions were unwilling to completely disengage themselves from the Empire. The method finally adopted for "the purpose of manifesting the special interest of the Dominions, while preserving the diplomatic unity of the Empire, was to have the treaties signed by the English plenipotentiaries for the Empire as a whole and then, in the same group of signatures, on indented lines, by the Canadian, Australian, South African, New Zealand, and Indian delegates for their respective parts of the Empire ". ${ }^{8}$ This method of signature will be scrutinised more carefully later when the Canadian Aerial Navigation Case ${ }^{20}$ is considered, because, in this instance, the Privy Council held that when treaties were signed in the manner just described (the so-called Empire Treaties), the Canadian Government had power to implement them. As will be demonstrated later,

10R, M. Dawson, The Development of Dominion Status, 1900.1936, 1937, p. 7.

${ }^{17 M a c d o n a l d, ~ o p, ~ c i t ., ~ p . ~} 587$.

${ }^{18}$ Dawson, op. cit., p. 33.

19P. E. Cortett and H. A. Smith, Canada and World Politics, 1928, p. 64.

${ }^{20}$ In re Regulation and Control of Aeronauties in Canada [1932] A.C., p. 54, bereinafter cited as the Aeronautica case. 
this narrow interpretation of Section 132 of the British North America Act has proved, at least in my opinion, to be very unfortunate.

After the introduction of separate signatures in the manner just described, it was a logical step to separate ratification of the peace treaties by each of the Dominions. As in the past the treaties were formally ratified in the name of the Crown, however, this ratification now took place only after separate approval of them by each of the Dominions.

The methods utilized to sign the peace treaties were short-lived, and in fact, by 1923, new practices were again being evolved. In that year Canada and the United States began negotiations with the object of drafting a treaty concerning halibut fisheries. The Canadian government requested from the King power for a Canadian representative, not only to negotiate, but also to sign the treaty. After some equivocation the British government finally agreed to the issuance by the Crown of formal Full Powers, which authorised the Canadian Minister of Marine and Fisheries to sign the treaty. Hendry notes that "this was the first tme in history a Canadian (and Dominion) appointee of the Canadian Government alone negotiated and signed a treaty with another power on behalf of Canada"."1

Particularly significant is the fact that the treaty touched on both political and commercial matters. One writer sagely suggests that the Canadian government was perfectly aware of this, and deliberately chose this particular treaty in order to establish a new precedent covering both commercial and political treaties. ${ }^{22}$ Canada's plans, however, were nearly frustrated by the U.S. Senate, which at first ratified the treaty on the basis that it applied to the United Kingdom and the British Empire. This interpretation was rejected by Canada and, after lengthy delay, the Senate accepted the Canadian argument. Dawson concludes by noting that "the final outcome of the incident was therefore satisfactory to the Canadian government. The evolution of the treaty-making powers had been carried a step further, and the Dominion had successfully asserted its right to negotiate and sign separate treaties with a foreign country without the participation of Great Britain"."

In 1923 the Treaty of Lausanne provided the next occasion for a further clarification of the treaty making position of the Dominions. ${ }^{24}$ The conference was called for the purpose of signing a peace treaty with Turkey. The Dominions, particularly Canada, were annoyed to find out not only that they were to receive no invitation, but also that the British government did not intend to include any Dominion representatives among her own delegation. ${ }^{25}$

${ }^{21}$ J. M. Hendry, Treaties and Federal Constitutions, 1955, p. 31.

22Dawson, op. cit., p. 71.

"aLoc. cit. For a description of the course of events with respect to the Halibut Fisheries Treaty from the viewpoint of an Englishman see: A. J. Toynbee, The Conduct of British Empire Foreign Relations Since the Peace Settlement, 1928, p. 101.104.

${ }^{24} \mathrm{~A}$ detailed account of the exchange between Canada and the United Kingdom concerning this whole question can be found in: Toynbee, op. cit., p. 85.92.

${ }^{25}$ Different authors offer different accounts as to why invitations were not extended to the Dominjons. The reasons are not vital to the present discussion, however. For an explanation of the British position see Toynbee, op. cit., p. $85 \mathrm{ff}$. The Canadian position is given by Dawson, op. cit., p. 77. 
Accordingly the position was taken by Canada that, since she had not participated in the conference, she would not sign the Treaty. She also refused to ratify it but recognised, nevertheless, that,

If the British government recommended the ratification of the Treaty, such ratification should also bind Canada. It was recognized that the whole British Eimpire would be bound as one when the Treaty was ratified. A distinction was made, however, between the international obligations thus assumed and the inter.Imperial obligations atising out of the Treaty. It was admitted that, internationally, Canada, as part of the British Empire, was legally bound by the Treaty, but it was insisted that the moral obligation resting on Canada was vastly different from that imposed on the countty under the treaties with Germany, Austria and Bulgaria. This difference arose from the different manner in which the whole negotiations had been conducted. 20

In October of 1923, an Imperial Conference of the British and Dominion Prime Ministers was called in London. The conflicts with respect to treaty making which had developed out of the negotiations of the Lausanne and Halibut Treaties called for an examination of this whole question by the Conference. Accordingly, a committee was set up to investigate the situation, and to attempt to resolve any problems or confusions which had developed. The committee at length submitted a number of proposals, and the Conference adopted several resolutions ${ }^{27}$ dealing with negotiation, signature, and ratification of treaties. With respect to negotiation, it was agreed that, when an Empire government is negotiating a treaty it should take into account its effect on the other parts of the Empire. Each country also agreed to inform other members of the Empire when it intended to negotiate a treaty likely to affect the interest of these other members. The stated idea was to allow other interested governments to express their opinions with respect to proposed treaties.

Regarding the signature of treaties, it was agreed that, where a bilateral treaty bound only one member of the Empire, only a representative of that member should sign the treaty. On the other hand, where the treaty "imposes obligations" upon any other parts of the Empire, then the government or governments affected must sign the treaty. Finally, it was provided that, at international conferences, the existing practice of signature by all Empire governments attending such a conference should be continued. Concerning ratification, the customary procedure was maintained. The Conference spelled this out to mean that ratification by the Crown is effected only at the request of the government assuming obligations.

The theories evolved at the Conference were tested and put into practice in 1925. Britain, in October of that year, signed the Locarno Treaty ${ }^{28}$ with His Majesty as the high contracting party. None of the Dominions desired to participate in the negotiation or signing of the Treaty. Since the European situation called for the British to act, they did so without the support of the Dominions. To resolve any doubts with respect to the position of the Dominions, Article 9 of the Treaty provided, "The present treaty shall impose no

${ }^{20}$ R. B. Stewart, Treaty Relations of the British Commonweolth of Nations, 1939, p. 165.

27The complete text of the 1923 Imperial Conference resolutions dealing with treaties can be found in Toynbec, op. cit., p. 105-106.

${ }^{28}$ A detailed examination of Locarno's significance for the Commonwealth is given in: A. G. Dewey, The Dominions and Diplomacy, v. 2, p. 240.276. 
obligation upon any of the British Dominions, or upon India, unless the government of such dominion, or of India, signifies its acceptance thereof."

This lack of unity provoked a great deal of anxious comment in Britain. "Mr. Ramsay Macdonald hailed it as the final breakdown of an Empire foreign policy which for three or four years had been on the verge of collapse."20 For our purposes the significance of Locarno lies in the fact that Great Britain "had concluded, for the first time, a vitally important political treaty which explicitly exempted the Dominions from its operation".90

The Imperial Conference of 1926 is one of the most important milestones in the evolution of the British Commonwealth. The most memorable and important part of the whole Conference report ${ }^{32}$ is the one which outlined the equal status of the self-governing sections of the Empire. "Their position and mutual relation may be readily defined. They are autonomous communities within the British Empire, equal in status, in no way subordinate one to another in any aspect of their domestic or external affairs, though united by a common allegiance to the Crown, and freely associated as members of the British Commonwealth of Nations." With this principle established as the cornerstone of the Conference the report considered in detail several important issues, among them the question of treaties.

Basically the principles of the 1923 Conference were retained and this Conference merely added "precision to the regulations of 1923 regarding the negotiation of treaties."." One new treaty innovation, however, was adopted, when the report proposed that treaties should be "made in the name of the King as the symbol of special relationship between the different parts of the Empire". ${ }^{22}$ This proposal was included in the report in order to clarify which parts of the Empire were actually entering into a treaty. It would make it clear that a plenipotentiary representing a Dominion was actually signing on behalf of the Dominion. It also guaranteed that the United Kingdom plenipotentiaries would sign only for the United Kingdom, and not for the British Empire. Thus, if a self-governing Dominion did not join in the negotiation and signing of a treaty, it would not be bound by the treaty's terms. Therefore, exempting clauses such as Article 9 of the Locarno Treaty, described above, would not be needed in the future. It also meant a return to the heads-of-state formula in treaty making, a formula providing that the King would be the high contracting party acting on behalf of the Dominion entering into the treaty. The practice, so widely used between 1919 and 1926, "of using the British Empire as the high contracting party, and of mentioning the Dominions and India (but not the United Kingdom) in the preamble, was condemned by the Imperial Conference".

Prior to 1919 treaties had been made in the name of His Majesty, but of

20Dawson, op cit., p. 102.

30Dawson, op. cit., p. 102.

31For the complete text of the Report of the Conference see: P. E. Corbett and H. A. Smith, Canada and World Politics, p. 195 (Appendix II)

s2lbid., p. 149.

${ }^{83}$ Stewart, Treaty Relations of the British Commonwealch, p. 181. 
course were either negotiated by the British representative or, if not negotiated by the British, were at least signed by one of their representatives. The utilization of the British Empire as the high contracting party was a convenient method of bridging the gap from control of Dominion treaty-making by Britain to the independence of the Dominions in such matters. This period is particularly interesting because it was unique in being the only time that the British Empire, eo nomine, was a party to a treaty. That is to say, the British Empire was the high contracting party, but each Dominion representative held powers from the king and signed separately for their respective countries on indented lines under the term "British Empire". The signatory countries then had the king ratify the treaty on behalf of the Empire.

This method of signature, however, concerns us in more than an abstract theoretical sense, because it was the basis of the decision in the famous Radio Communications Case. ${ }^{34}$ As this case will be dealt with in some detail later regarding the question of implementation, only a brief examination of the decision will be made here.

Canada was a signatory to the International Radio Telegraph Convention, having signed as a separate soverign state in her normal alphabetical position, following the principles outlined at the Imperial Conference of 1926. Implementation of the terms of the treaty was challenged, and the matter came before the courts. The government of Canada argued that Section 132 of the British North America Act provided them with the right to implement the treaty. The Privy Council rejected this argument and maintained that Section 132 had been previously interpreted to apply in the Aeronautics Case, to, "a treaty between the Empire as such and foreign countries, for Great Britain does not sign as representing the Colonies and the Dominions". Without, at this point, going into detail, it should be made clear that this narrow opinion is unfortunate, not only because it hinders Canada's political development, but also because it is completely insupportable in terms of the history of the evolution of the treaty power in the Dominions. Nevertheless, the whole problem raised by the Radio Communications Case points up the importance of understanding the historical aspects of treaty problems.

It is practically impossible and certainly unnecessary to review all the treaties and agreements entered into since 1926 in order to determine the practical effects of the Imperial Conferences of 1923 and 1926. A brief examination of the negotiation and ratification, in 1928, of the Treaty for the Renunciation of War, however, admitably serves to illustrate the practical results of these two conferences.

The United States desired the signing of an agreement calling for the renunciation of war. An invitation to participate in the Treaty was sent to the British government, but the self-governing Dominions were ignored. The British replied that they refused to participate unless the Dominions were also invited to participate in the negotiations. The United States accordingly

34In re Regulation and Control of Radio Communications in Canada, [1931] S.C.R. p. 541;

[1932] A.C. p. 304. Hereinafter referred to as the Radio Communications Case.

s5[1932] A.C. p. 311. 
issued invitations to the Dominions and to India, and they, in turn, accepted. The proposals of the Imperial Conferences were adopted with respect to form and ratification of the Treaty.

The Heads-of-State form was utilized, with the King being the high contracting party for each member of the Commonwealth. Similarly, with respect to ratification, the King separately ratified the Treaty for each of the Dominions. That is, he ratified only "in respect of Our Commonwealth of Australia" or "in respect of Our Dominion of Canada". I feel that Professor Stewart is justified in his assertion that, "The procedure followed at every step in the conclusion and ratification of the Treaty for Renunciation of War demonstrates how completely the resolutions of the Imperial Conference of 1926 had been carried into effect and how fully the international status of the Dominions was thus recognized by the United Kingdom and by foreign powers." ${ }^{\text {sa }}$

The Imperial Conferences of 1923 and 1926, however, recognized another type of international agreement besides the heads-of-state form utilized in the Treaty for the Renunciation of War; namely, intergovernmental agreements. ${ }^{37}$ These agreements, which are used in both Canada and Australia, do not require the intervention of Her Majesty. They are agreements made only in the name of the participating governments. ${ }^{38}$ This classification is useful because it enables international agreements to be made without requiring full powers from the head of the state. This has proved very useful in expediting the conclusion of treaties, since, as Mr. Justice Read points out, "When an international agreement has been negotiated in point of form between governments, the full power is a much simpler matter. The only formal requirement is a written authority, signed by the Secretary of State for External Affairs. ${ }^{\circ 0}$ It may, but need not necessarily, include his seal or the seal of the department. An intergovernmental agreement just as binding as one concluded between heads of state and its validity is not affected by change of governments".40 With respect to the question of ratification of intergovernmental agreements, as might be expected, "both the full power and the instrument of ratification may take the form of documents issued by the Minister for External or Foreign Affairs"."

In 1947 the "Letters Patent Constituting the Office of Governor-General of Canada"12 was passed by the Canadian Parliament. These Letters Patent provided as follows: "And we do hereby authorize and empower Our GovernorGeneral with the advice of Our Privy Council for Canada or of any members thereof or individually, as the case requires, to exercise all powers and authori-

\footnotetext{
30Stewart, op. cit., p. 192.

37For a careful examination of this whole question in relation to Canada see: J. B. Read, "International Agreements", 26 Can. Bar Rev. 1948. Mr. Justice Read is a member of the International Court of Justice.

${ }^{39}$ As the procedure in both countries with respect to the conclurion of an agreement is identieal they will be dealt with together.

BDIn Australia by the Minister of External Affairs.

10Read, op. cit,, p. 192.

11 Ibid, p. 523.

"For the text see: W. P. M. Kennedy, "The Office of Governor.General in Canada," University of Toronto Lax Joumal, v. 7, 1947-48, p. 474-483.
} 
ties lawfully belonging to Us in respect of Canada".43 The effect of these Letters Patent is to vest in the Governor-General the same authority to issue full powers and instruments of ratification as is possessed by the Queen. The Prime Minister of Canada outlined the Government's view of the effect of the Letters Patent, in the Canadian House of Commons, in this way: " . . . this does not limit the King's prerogatives. Nor does it necessitate any change in the present practice under which certain matters are submitted by the Canadian Government to the King personally. However, when the Letters Patent came into force it will be legally possible for the Governor General, on the advice of Canadian ministers, to exercise any of these powers and authorities of the Crown in respect of Canada, without the necessity of a submission being made to His Majesty. The new powers and authorities conferred by this general clause include among others royal full powers for the signing of treaties, ratifications of treaties, and the issuance of letters of credence for ambassadors ..."

Thus in Canada the full powers to make a heads-of-state treaty can now be issued either by the Queen, or by the Governor General. It is of course well recognised that in either of these situations action would be taken only upon the advice of the Canadian Cabinet. There seems little reason now for obtaining full powers from the Queen, when the same result can be achieved through the offices of the Governor General, in which case "the procedural steps would be greatly simplified, and confined to Ottawa". ${ }^{45}$ The practical importance, however, of the heads-of-state form has been rapidly declining in re. cent years. Professor Stewart points out that "in Australia, as is true also with the other Dominions and with the United Kingdom, most international engagements are now concluded in the form of agreements between governments". ${ }^{\circ 0}$ As has been outlined previously, full powers of negotiation and ratification in both Australia and Canada are issued by the nations' foreign ministers. The only difference between these intergovernmental agreements and the heads-of-state form is the fact that the latter is made in the the name of the Crown, whereas intergovernmental agreements are made solely in the name of government.

Before concluding this section, it should be pointed out that, not only is a similar proceedure with respect to intergovernmental agreements followed in Canada and Australia, but also in the case of heads-of-state treaties. This is indicated by a memorandum forwarded to the United Nations from the Australian Mission to the United Nations, on the question of treaty practices in Australia." The memorandum states, "Although the Queen is the Head of State in Australia, her executive powers in Australia are exercisable by the

\footnotetext{
${ }^{43}$ Kennedy, op. cit., p. 475.

14House of Commons Debates (Canada), 1948, p. 1126.

45Read, op. cir., p. 524.

46 Stewart, op. cit., p. 251.

-T The Secretary.General of the U.N. requested from alt the member states "information relative to their national laws and practices in the matter of the conclusion of treaties". Unfortunately, many of the replies are quite brief, in the case of Australia amounting to no more than two pages. Furthermore, the Australian memorandum contained no material on implementation. U.N. Legal Dept., Laws and Practices Concerning the Conclusion of Treaties (U.N. Legislative Series) 1953. p. 5.
} 
Governor-General, and whereas, prior to the Second World War, it was customary to obtain from the Queen in London full powers for Australian plenipotentiaries in treaty-making of a formal kind, the constitutional conventions of the British Commonwealth of Nations have altered by reason of the increased international status of the member nations, and it is now customary for the Governor-General to confer the necessary authority on Australian representatives". ${ }^{48}$

Any study of the procedures necessary to negotiate and ratify treaties in Australia and Canada would be incomplete without reference to the role of Parliamentary responsibility in this process. It seems quite clear, in theory, that the negotiation and ratification of treaties is an executive act, not tequiring parliamentary action. This principle is underlined in both the Australian and Canadian memorandums to the United Nations. The Canadians described their legal practice as follows: "There is no law imposing any obligation on the Government of Canada to refer treaties or other international agreements to the Parliament of Canada for approval prior to ratification. International obligations are entered into in many instances without reference to Parliament. The negotiation and conclusion of a treaty or other international agreement is an executive act". same lines. They stated, "It is the general practice, however, for agreements of major political significance to be submitted to Parliament for approval before ratification, but the act of ratification, nevertheless, is an executive act."

There is a great deal of practical political wisdom in having treaties approved by Parliament before ratification, even though, technically, parliamentary action is unnecessary. Certainly when a treaty is going to require implementation by domestic legislation it is advisable for the Executive to take Parliament into its confidence and ask its approval before ratifying the treaty in question. Similarly, when a treaty touches on important matters of policy, political common sense would certainly suggest that parliamentary approval be obtained before ratification. Mr. Justice Read states that "in Great Britain the practice has been to table all agreements, thus giving to Parliament the opportunity to consider them at any time, and to limit formal approval to specially important cases. In Canada all international agreements, including exchanges of notes, are tabled, regardless of whether further action is to be taken in Parliament":"1 Legally, it is quite clear that parliamentary action is not needed to enter into any form of international agreement, but practical considerations usually require that parliamentary approval be obtained before ratification.

\section{End of Part I}

(Part II will appear in the next issue.)

48Ibid. p. 6.

19U.N. Legal Dept., op. cit., p. 24.

solbid., p. 6.7.

s1Read, op. cif., p. 527. 